\title{
Dark Triadの短期配偶は配偶者保持行動に媒介される
}

\author{
$\bigcirc$ 喜入 娔 ${ }^{1} \cdot$ 越智啓太 $^{2}$ \\ ( ${ }^{1}$ 法政大学大学院人文科学研究科 ${ }^{2}$ 法政大学文学部 $)$ \\ キーワード : Dark Triad, 配偶者保持行動, 短期配偶
}

\begin{abstract}
Mate retention behavior mediates the relationships between the Dark Triad and the short-term relationship Satoru KIIRE ${ }^{1}$ and Keita $\mathrm{OCHI}^{2}$

( ${ }^{1}$ Graduate School of Humanities, Hosei Univ., ${ }^{2}$ Faculty of Letters, Hosei Univ.)

Key Words: Dark Triad, mate retention behavior, short-term relationship
\end{abstract}

\section{目 的}

社会的に望ましくないパーソナリティの集合体である Dark Triad は, マキャベリアニズム, ナルシシズム, サイコパシー から構成され，冷淡さや他者操作性がその中核である

(Paulhus \& Williams, 2002; Furnham et al., 2013)。しかし，進 化的観点からは, Dark Triad は繁殖において有利な戦略をとる 可能性が指摘されている (Jonason et al., 2009)。繁殖のための 戦略は，単純化すれば，資源を子どもの生殖に割り振るか, 子どもの養育に割り振るかというトレードオフにある。この ように，資源の割り当ての個人差を，遺伝的基盤と幼少期の 環境的キューによる進化的な戦略の個人差であるとして理論 化したものは，生活史理論（life history theory: LHT）と呼ばれ る（Figueredo et al., 2006）。生活史理論は，戦略の個人差を K-factor という一次元で捉える（Rushton, 1985）。次元の両極 は, 早い生活史戦略 (fast-LHS) と遅い生活史戦略 (slow-LHS) である。遺伝的基盤に加えて, 将来の見通しが立つ安定的な 環境に置かれた場合には戦略の個人差は slow-LHS，具体的に は，長期的な計画性や他者との協力などが有利な行動パター ンである。一方で, 将来の見通しが立たない不安定な環境は, 戦略の個人差として fast-LHS，具体的には，衝動的で自己中 心的行動が有利である。先の繁殖のための戦略は，生活史理 論に照らせば, slow-LHS は長期的配偶により少数の子どもを 確実に生存させる（養育する）ことが，fast-LHS は短期的配 偶により多くの子どもを生殖することが，繁殖可能性を高め る適応的な行動パターンである（Figueredo et al., 2006)。

一方で, Dark Triad が高いものは低いものに比べて配偶者保 持行動をより行なうことが示されている (Jonason et al., 2011) 配偶者保持行動は, パートナーとの関係維持のための行動で ある（Buss et al., 2008）。したがって，短期配偶を特徴とする という Dark Triad の知見と矛盾するように見える。

しかし，Dark Triad の配偶者保持行動は，長期的な関係維持 というよりもむしろ，生殖を行なうための一時的に強力な束 縛の可能性が示唆されている（Kiire, 2017)。これによれば, 生殖を重視する，特に男性で Dark Triad が高い者にとって, 父性不確実性の問題は特に大きな適応課題である。そのため, 過剩な配偶者保持行動を行ない，一時的であっても強力なパ 一トナ一関係維持を行なう反面，比較的短期に関係が終了す る可能性が考えられる。そして，このことが Dark Triad の短 期配偶を促進している可能性が考えられる。これらを踏まえ， 本研究では, Dark Triad が高い者ほどこれまでのパートナー数 が多いことを示し，その関連を配偶者保持行動が媒介寸るか どうかを検証する。

\section{方 法}

参加者 大学生 540 名 (女性 313 名, $M_{a g e}=18.84, S D=1.41$ ) を分析に使用した。

測定 参加者は，Short Dark Triad（SD3；下司・小塩，2017; 27 項目， 7 件法），配偶者保持行動目録日本語版（寺島, 2010;
38 項目，4 件法）に回答し，これまでのパートナー数を報告 した。それぞれ，平均得点を尺度得点とした。なお，参加者 は，本研究では用いない尺度も含めて 142 項目に回答した。 結 果

進化的観点において, 性別と年齢は注意深く扱う必要があ る。そのため, 本研究では, す心゙ての分析において性別と年 齢を統制変数として投入した。はじめに，SEMにより，パー トナ一数を目的変数, Dark Triad 因子を説明変数とした回帰分 析を行なった。分析の結果，有意な正の効果が示された（b= $1.55 * *)$ 。次に，この関連を配偶者保持行動因子が媒介寸るか どうかを 5000 回のブートストラップ法により検証した。分析 の結果, Dark Triad からパートナー数への効果は配偶者保持行 動に完全媒介された $\left(\chi^{2}(39)=177.29, p<.001 ; \mathrm{CFI}=.922\right.$; $\mathrm{SRMR}=.046 ; \mathrm{RMSEA}=.081,90 \% \mathrm{CI}=[.069, .093]$; Fig. 1$)$ 。

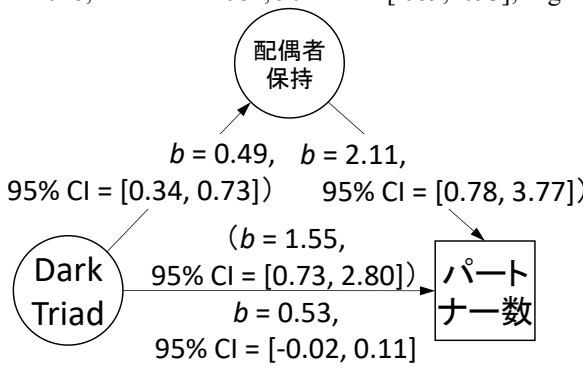

Fig. 1. 媒介分析の結果。間接効果は有意であった $\left(b_{\text {indirect }}=1.03,95 \% \mathrm{CI}=[0.38,2.19], 5000\right.$ bootstraps $)$ 。

（）内は媒介変数を投入しない場合の結果を示す。

\section{考 察}

結果より, Dark Triad はパートナー数と正の関連を示し, こ の関連は配偶者保持行動に媒介されることが示された。これ らのことから, Dark Triad の強力な配偶者保持行動が比較的短 期的にパートナー関係を終了させ，それに伴いパートナー数 が増える可能性が示された。しかし, 本研究の知見からでは, Dark Triad の強力な配偶者保持行動が実際に関係の終了に影 響しているかどうかは不明瞭である。また，生殖のためには 正式な交際宣言をしたパートナーの人数ではなく，性関係を 持った人数が重要である。そのため, 今後の研究では, 性関 係を持ったパートナー数と, 配偶者保持行動の結果に着目す ることが必要であると考えられる。

\section{主要な引用文献}

Buss et al. (2008). Personality and Individual Differences, 44, 322-334.

Figueredo et al. (2006). Developmental Review, 26, 243-275.

Furnham et al. (2013). Social and Personality Psychology Compass, 7, 199-216. 